\title{
The legend of Achaneh: Socio-ecological knowledge in the oral tradition of fisherwomen in Veracruz, Mexico
}

\author{
Juan Carlos A. Sandoval-Rivera, Universidad Veracruzana, Mexico
}

\begin{abstract}
Based on ethnographic fieldwork conducted in an indigenous community of Veracruz, Mexico, traditional socio-ecological knowledge was identified embedded in the oral tradition of fisherwomen of the local community. The reflections presented show the educational potential of indigenous knowledge that, from their own epistemology, has allowed the inhabitants of this community to regulate the way in which they relate to each other and to their environment in a sustainable way over the centuries. The findings presented in this article bear testimony to the socio-environmental relevance of these local indigenous narratives as situated philosophies which are important to document so as to move towards a scenario of sustainability arising from a dialogue between the local and the global.
\end{abstract}

Keywords: oral tradition; socio-ecological knowledge; indigenous knowledge; education for sustainability.

\section{Resumen}

Durante un trabajo de campo etnográfico realizado en una comunidad indígena de México, se identificó en la historia oral de pescadoras de la comunidad, la presencia de conocimientos socio-ecológicos afines al paradigma de la sustentabilidad. A partir de las historias recopiladas durante la investigación realizada, se muestra el potencial educativo del conocimiento indígena que, desde su propia epistemología, ha permitido a los habitantes de esta comunidad regular la forma en la que se han relacionado entre sí y con su entorno a lo largo de los siglos. Los hallazgos presentados en este artículo dan testimonio de la relevancia socioambiental de estas narrativas indígenas locales que se retoman como filosofías situadas, las cuales pueden ser importantes en el tránsito hacia la sustentabilidad a partir del diálogo entre lo local y lo global.

Palabras clave: tradición oral; conocimiento socio-ecológico; conocimiento indígena; educación para la sustentabilidad. 


\section{Introduction}

In this article, I will present some reflections concerning indigenous socio-ecological knowledge contained in the oral tradition of Nahua fisherwomen (see Figure 1) in the Zaragoza community in southern Veracruz state, Mexico. These stories were recorded in interviews, informal conversations and audiovisual recordings of the fisherwomen's accounts, as well as participant observation of the various fishing tasks carried out by the women. This was all recorded in this indigenous community during the fieldwork conducted for my doctoral research.

The legend of Achaneh is part of the oral tradition in Zaragoza that, for centuries, has been passed on from generation to generation, mainly among the people who participate in traditional fishing practices. In the story, Achaneh is a woman who owns all the bodies of water in the community. She takes care of the water and is therefore also the owner of all the creatures that live in the water. If anyone wanted a good catch, they would have to make an offering to her or remain respectful, both towards people and towards the environment, otherwise their fishing would not go well. Some people from the community who have already passed away, swore that they had seen her. 'The Legend of Achaneh', as it is known in the community, has been embellished and rearranged through many accounts which, across the centuries, have been passed down in order to teach ethical principles relating to coexistence and a respectful use of natural resources.

Figure 1. Fisherwoman

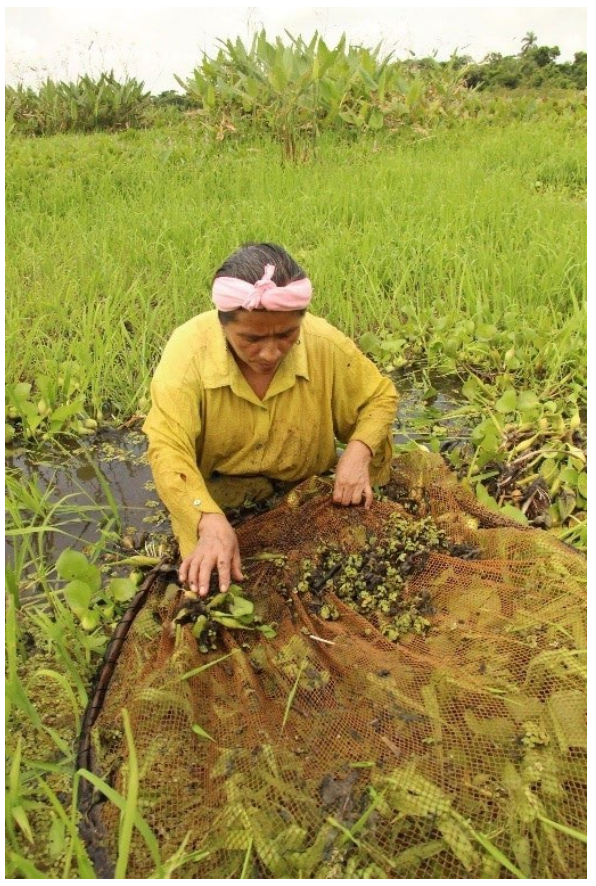




\section{What is indigenous socio-ecological knowledge, and why is it relevant to the field of education?}

Knowledge that has been constructed by indigenous peoples (indigenous ways of knowing and doing) has been given several names: 'indigenous knowledge', 'endogenous knowledge', and 'traditional ecological knowledge', among others (Shava, 2013). Before arguing for its relevance, I will define what I mean by the term 'indigenous knowledge'. I will take up the definition of Grenier (1998:1-2), who refers to knowledge that is:

[...] unique, traditional, local knowledge existing within and developed around the specific conditions of women and men indigenous to a particular geographic area [...]. Indigenous knowledge is stored in people's memories and activities and is expressed in stories, songs, folklore, proverbs, dances, myths, cultural values, beliefs, rituals, community laws, local language and taxonomy, agricultural practices, equipment, materials, plant species, and animal breeds. Indigenous knowledge is shared and communicated orally, by specific example, and through culture.

One characteristic of indigenous knowledge is that it is related to every aspect of life, including, of course, the ecosystems on which communities' survival has depended. Since these systems of knowledge are cumulative, they represent generations of experience and careful observation, and are the result of experiments developed over thousands of years. It is knowledge that is encrusted in the very culture and embodied in its practices (Shava \& O'Donoghue, 2014). Therefore, it is knowledge that is generated in a specific local context in response to specific local problems (George, 1999).

Maurial (1999:63) notes that indigenous knowledge is 'the result of the quotidian interactions in indigenous peoples' territories. These interactions occur among families, communities and indigenous peoples. Indigenous knowledge is immersed in the whole culture and is recreated through successive generations. The essence of indigenous knowledge is that it is alive in indigenous peoples' culture. Different from western knowledge, it is neither in archives, nor in laboratories. It is not separated from everyday peoples' lives. In educational terms, Kincheloe and Steinberg (2008) consider approaching indigenous knowledge as necessary to counteract the destruction of our planet that the daily workings of western science lead us to cause.

From the academic and scholastic fields, a recognition of the value of indigenous knowledge allows us to analyse reality and its challenges from a range of perspectives that can help to focus and channel our efforts toward solve the problems now facing humanity. The more perspectives we can consider, the closer we get to understanding reality (Reynar, 1999). In this way, different frames of reference create multiple interpretations and multiple realities. A multi-logical and diverse epistemology and ontology support a detachment from reality that allows us to observe reality from the points of view of diverse ontological (Stetsenko, 2008) and epistemological (Santos, 2006) frameworks. Hence, in relations between actors coming from different epistemological frameworks, there may be complex matrices of interaction, codes and meanings that can create a dialogue to encourage understanding. In order to promote dialogue 
between different kinds of knowledge (indigenous and non-indigenous), the biggest challenge is to perpetuate the cultural systems that produce the indigenous knowledge (Kincheloe \& Steinberg, 2008) more than the knowledge itself.

Similarly, concepts derived from the perspectives of those who have historically been excluded allow us to visualise the power of difference, the processes of oppression and the limitations of monocultural ways of building meaning (Reynar, 1999). Kincheloe and Steinberg (2008) note that the multi-logical understanding of a particular reality is a new kind of logic, unrecognised by the 'sleepwalking' dominant culture. Therefore, the political stance behind this position can be considered as alerting us to the form in which we normally give meaning to reality: the academic-scientific perspective. It is worth noting that, being contextualised in its production and use, indigenous knowledge is difficult to reproduce or universalise, since the contexts in which it is produced change according to where it can be reproduced, especially if we seek to use it in contexts of conventional scientific research or in the framework of official education.

\section{Education, indigenous knowledge and the Sustainable Development Goals}

The Sustainable Development Goals $(\mathrm{SDGs})^{1}$ (UNESCO, 2015) are presented as a complex collection of desirable elements in the drive for sustainability, in which education clearly has a relevant role to play. It is not necessary to point out the contemporary problems that modernity and our present economic model have caused for our planet in order to recognise that this international agenda is pertinent to shaping our future by carrying out urgent actions in the present. Nevertheless, the discourses presented by this agenda show us a series of socioecological problems and challenges through 17 goals that are not easy to decode and work on at a local level, above all due to the variety of ways in which what is stated may actually be understood. In the same way, the concept of sustainability can also be difficult to understand due to its symbolic and sometimes rhetorical connotations (González-Gaudiano, 2001) associated with the SDG concept since it first appeared. Thus, in indigenous contexts, it is relevant to talk about complexity in visualising and orchestrating the transition towards sustainability using the SDGs as a guiding tool, when we start, for example, with the fact that, in Mexico, there are around 364 varieties of indigenous languages (INALI, 2008).

Following on from this, during an exploratory study in indigenous communities in Mexico in 2015 and 2016, it was observed that the implementation of the SDGs has not been easy, when issues of social and ecological justice are not dependant on local factors, but rather on external ones, or where the concerns of indigenous peoples have not been carefully considered in an inclusive way. Faced with such complexity, the need arises to recover knowledge practices still present in indigenous regions (Bishop, 1995) that permit an exploration of how, in the transition towards sustainability, social and ecological well-being are visualised in indigenous world views (Boff, 2013), and how they can be coordinated with the dispositions and expectations for indigenous peoples contemplated in the SDGs.

Implementing education directed towards socio-ecological transformation is not an easy matter. Nevertheless, if we recognise that there are still philosophical (ethical-political) perspectives that, on the margins of modern society, have been able to produce and maintain 
healthy socio-ecological systems (such as indigenous philosophies reflected in oral folktales), we can include them in educational schema directed towards sustainability and find out how local and international perspectives and agendas can complement each other.

\section{Indigenous knowledge and sustainability}

In the worldviews and practices of indigenous peoples, we find the clearest examples of civilising proposals that focus their attention on balance and life; and which therefore constitute the sustainability we seek (Boff, 2013). However, in a global and modern context full of injustice and contradictions, a community (indigenous or not) can be considered sustainable when it takes (or recovers) control of the processes that determine or affect it (Toledo, 1996). In this way, if a community has ceased to be sustainable for whatever reason, the first action that the whole community should carry out to regain socio-ecological balance is to take control of their territory; that is, to manage their ecosystems in an adequate, non-destructive way, which is achieved by means of the knowledge available to take the necessary decisions. In a globalised world, this knowledge could come from several sources: from technical staff in development agencies or non-governmental organisations (technical knowledge); from the academic field (scientific knowledge); or, as shown in this article, from the knowledge created and transmitted from generation to generation (indigenous knowledge).

Therefore, faced with the complexity of the socio-ecological challenges before us in the present day world, we need to recognise epistemological pluralism from this range of sources of knowledge (Olivé, 2009) in order to lay the foundations for an inter-epistemic dialogue in which indigenous philosophies cease to be subjugated knowledge and instead take on a leading role in the decisions that affect all societies.

The indigenous peoples of the world have, over time, maintained a close relationship with the ecosystems with which they have coexisted; their very contact with nature has allowed them to create knowledge and practices connected to nature in order to survive. Similarly, their ecosystems have determined the way in which these communities have adapted to their environment, influencing the development of their knowledge and practices.

There is significant evidence showing that those parts of the world rich in biological diversity are also areas with high linguistic diversity. ' $[\mathrm{N}]$ ine of the twelve main centres of cultural diversity (in terms of the number of languages) are also on the list of biological megadiversity and, reciprocally, nine of the countries with the greatest variety of species and numbers of unique species are also listed in the 25 countries with the highest numbers of native languages' (Toledo, 2003:67-69). This statement constitutes an emerging paradigm in which cultural diversity is connected to biodiversity, each being interdependent on the other (SandovalRivera, 2015).

\section{The legend of Achaneh, fishing and crocodiles}

In this section, as evidence supporting the above claims, I will present accounts of the socioecological importance of the stories told by the fisherwomen concerning the management 
of their environment. The stories were transcribed in their entirety with no editing, with the intention of showing the whole narrative contained in these accounts in which the relationship between fishing, crocodiles and Achaneh is identified. The message of the Legend of Achaneh, according to the fisherwomen interviewed, tries to teach values and the regulation of human behaviour for the improved coexistence of the community and its environment. Around this knowledge, as expressed in the oral folktales, interrelations between traditional fishing, the biological conservation of the species of crocodile found in the region (Crocodylus moreletii) and the sustainable management of ecosystems from a local viewpoint, can be identified.

In the accounts, the close relationship between the fishing sites and the places where the crocodile lives can be discerned:

Firstly, I have been told that the crocodile is an animal that's closely related to fishing. My uncles, who've now passed away, used to tell me that where there is a crocodile that means there are fish. I don't know why, but they always used to tell me, 'Where you see a crocodile, go and fish there, because you're sure to find fish.' (Lucía, fisherwoman)

Similarly, they try to explain through the relationship between the crocodile and the fishing, the role the crocodile plays in the ecosystems:

I think the crocodile is an animal that's in the water to regulate fishing. The presence of a crocodile in a place means there are fish there. And the crocodile is also there to make sure nobody takes all the fish. That's the crocodile's function. Besides, where there's a crocodile there will always be bodies of water and so there will always be places to fish. And that's why we shouldn't kill them. (Juana, fisherwoman)

Another account agrees with the previous one concerning the role of the crocodiles and the way in which Achaneh and the crocodiles are related:

The crocodile's role is to take care of the fish, he brings the fish, the fish go with him; where there is a crocodile there are many fish, and when he goes, he takes the fish with him. My mother says that once they killed a large crocodile, it was out of the water, sunbathing, and a man found it and killed it. This man was told in a dream not to go fishing anymore, because if he did, he wouldn't be coming back home. They say that when he wanted to go fishing one time, many crocodiles appeared and chased him. That is the crocodile's role: to take care. And our grandparents say that the crocodiles are like Achaneh's dogs, because they're the ones who take care of her home so that nobody damages the rivers and lakes. (Julia, fisherwoman)

In other accounts we can identify that the importance of the crocodile is not only ecological but also cultural. Some messages are identified relating to moral values for family life. The following account is a clear expression of the punishment of a person who does not respect the rules established by the 'owner of the water', and the account thus corresponds to the connection between Achaneh and the crocodiles for regulating community members' behaviour: 
My grandparents used to say that it was the same crocodiles that were there in the water that would threaten people. My grandfather says that he knew a man called Pedro, and this man went fishing a lot, but he had another woman, and instead of taking food to his children he took food to the other woman who wasn't his wife, and the owner of the water didn't want him to do that. He used to get very sleepy every time he went fishing and sometimes he fell asleep while he was fishing. The first time he fell asleep while he was fishing, he says that Achaneh told him in a dream not to fish, that if he did, he should take the food to his children. But as the man had another woman, he couldn't take food to his own children, because he had promised to take it to the other woman. The second time he went, the same thing happened in his dream, Achaneh kept telling him not to fish, or if he did, he was to take the food to his children, because if he didn't, he wasn't going to make it back home. The man didn't take these messages seriously even though he received a third message while he slept; Achaneh told him not to go fishing anymore, because if he did, something bad would happen to him, and it's true, it happened. It happened to him because the third time was the last; when he went, they say that a great crocodile appeared and bit him. With the bite the crocodile cut off his leg; they say the man shouted in the water, calling for help, but who would hear him in the lake? They say the crocodile followed the man as he dragged himself along until he managed to get away from the lake shore, but he was severely wounded. The next day the crocodile found the man and ate him. Our grandfather told us, he said that his father saw this happen, and, well, he says that's what happened and it's true. My grandfather always told us how it happened and says that above all he guided us because the water is sacred, 'They won't do you any harm when you do what's right'; at that time the water was very sacred, but not so much now. (Olivia, fisherwoman)

A relationship is also established between the presence of a crocodile and very deep fishing spots, as well as a proportional relationship between the number of crocodiles that can be found in a body of water and the quantity of fish that may be caught there:

My uncle used to tell me, 'Look, when you go fishing and you see a crocodile, go in carefully because it's sure to be deep there.' Those who live from fishing say that when a crocodile passes by there are normally fish. Where there's a crocodile, there are fish, but where there are several crocodiles there are lots of fish. They say it's because the crocodiles attract them. I have my own reasoning, but all the same it might just be mine; I suppose it's a way fish have of protecting themselves from people. Because the fish know that a fisherman isn't going to get in the water where the crocodile is. Here we have the belief that the crocodile draws the fish in, that he attracts them. And it's true because, for example, there's a place called Estero Mudo [Silent Marsh], there are a lot of pools there that are very deep, too deep, and people hardly go fishing there, and they say there is a really good stock of fish there, a variety of fish too, but they hardly dare fish there because it's very deep and the crocodiles are there. (Juana, fisherwoman)

There is a relationship between the legend of Achaneh and the crocodile, and also other species that live in the wetlands in the region such as a species of turtle that has as much to do with the balance of community living as it does with that of the management of ecosystems. These 
relationships between species and knowledge make up part of the local worldview and of what is passed on in the oral traditions of Zaragoza:

The legend tells us that the crocodile is not the owner of the water, the owner is really Achaneh, and as the owner she has the crocodiles among her animals, just as we keep pets. The crocodiles are Achaneh's dogs; and the big turtles, those white ones, that there are almost none left of, and that are rarely caught, that's where Achaneh sits. Here we used to have, many years ago, where we used to sit, a kind of stool made of wood, and that's why people a long time ago believed that Achaneh took those turtle shells as seats, but of course she used to take them with the turtle still alive. And they believed that these animals [the crocodiles and the turtles] obey the voice of Achaneh. In that respect they consider the crocodile to be a dog and that it's in charge of taking care of the bodies of water. Because Achaneh doesn't come, she's not the one who directly chastises you for doing or not doing something, rather she sends her animals to give you the message. But that's only if you're going to do something bad in the water or if you're going to do something that will destroy the habitat that they are in. But if you treat them with respect and fish properly, which is just to feed your family, then there is no problem and you can go there even if there are crocodiles. (Juana, fisherwoman)

In the relationship between Achaneh and fishing, there are also mechanisms that regulate the number of fish that can be caught by a single person. This is fundamental in ecological terms and in terms of managing ecosystems, since ecosystems have a limit to what can be taken from them without their deterioration. From this perspective, this ecosystem management is found in the legend itself and in the knowledge of the fisherwomen, as the oral tradition recommended rationing fishing in the community:

Our grandparents also used to tell us that when fishing you have to catch what you're going to need and no more, because other people need to fish too. That's the way our ancestors thought: 'Take what you're going to eat, and that's more than enough, don't look at it with greedy eyes.' That's to say, I've found a place and I'm going to catch all that I can, even though one day it will run out. Normally when they went fishing, they would bring back a fair quantity in their tecomate $^{2}$ [see Figure 2], or maybe in a moral. ${ }^{3}$ Enough for two, three, four days or even up to a week. Once they've finished that, they go out fishing again. So that's how they normally used to fish. Later there was a time when it was done for commercial purposes, but a long time ago it was exclusively for personal consumption. (Olivia, fisherwoman)

Some accounts try to explain the reasons why fish stocks are depleted, and they have to do with the idea that Achaneh is upset because the bodies of water she owns have become polluted. The people in the community who see this legend as a reality say that Achaneh has not gone away, she is just hidden, and the place she is hiding in is where she has taken the fish. Even today stories are still told relating to the legend of Achaneh, they even speak of a place where people believe that she is hiding. In the following account, I share a recent story with the same characteristics of the legend, which happened in the past when the legend was still current. 
This account shows how, although the legend is seen as belonging to the past, it is still a current issue for some inhabitants:

In Estero Mudo [Silent Marsh] people hardly go there to fish, well some elders say that many years ago Achaneh was all around because she could move about. But as the place where she lived became more and more polluted, she was pushed back until she was in Estero Mudo. They say that's where she went and hid because it's more difficult to get in there. And most people who talk about it, as they say that very few people have gone fishing in Estero Mudo, because it's very deep there. The water lily bed there is a metre or a metre and a half thick, and you don't know if you're walking on water or on land. So it's dangerous to fish there because it's very deep and there are a lot of crocodiles, so people respect the place. There is more variety of fish there, and lots of turtles. I know there are because my brother-in-law has been fishing there. And there's something noteworthy, because he used to go fishing alone and would bring back seven to ten turtles in one fishing trip. But once some people who live in the city heard that Estero Mudo was a good place to fish, and my brother-in-law took them fishing there, but when they got there, they didn't find anything. Later, when my brother-in-law went again by himself, he didn't catch anything and wasn't able to bring anything home to eat. So the old men here told him, 'The thing is, Achaneh used to give them to you because you have limited economic means. Achaneh gave them to you because you needed them, but you brought rich people who have buses, they have cattle, they have land and live in luxury, well of course she wasn't going to give them any fish. Then, as you brought them, so Achaneh punished you and took away her fish.' I don't know if it's a coincidence, but that really happened. (Roberta, fisherwoman)

Other more or less contemporary accounts agree with the idea that Achaneh now lives in bodies of water that are hard to reach. In the following account, it is claimed that Achaneh's messages are still heard; especially with recommendations to avoid polluting the bodies of water:

There is a river in the community that's about nine metres deep and there are lots of crocodiles there, you can still fish there, but only from the bank. And there's a place there where the elders say that Achaneh was there, because that river in the dry season is cut off, but when it's full it's very deep and there's a place where it joins a lake through an underground river. There in that underground river is where Achaneh lives now. We heard about an old man who had some land there near the lake and he lived there for a while; he heard in dreams that people shouldn't tip soapy water into the lake and that they should stop dirtying it. And when he went fishing, she would talk to him, Achaneh asked the man for his ribbon and his mamey-zapote seed oil; once she revealed to him that if he told people they weren't to pollute the lake, she would give him a present when the rainy season began. He did what he was asked, and she rewarded him with very big fish. (Felícita, fisherwoman) 
Figure 2. Fisherwoman with her tecomate

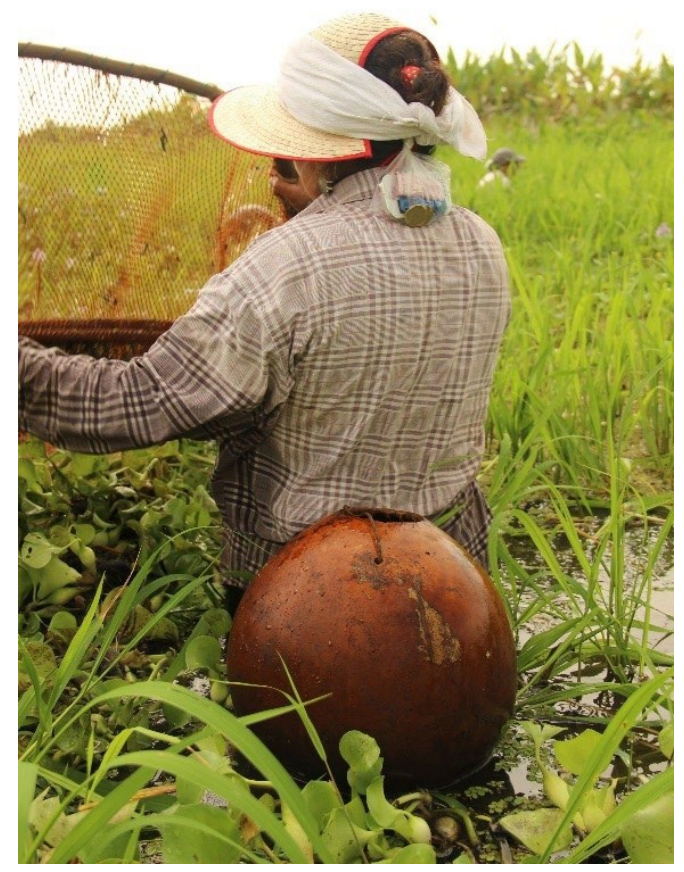

Source: Author

\section{By way of a conclusion}

Education is a key element within the framework of the SDGs in indigenous peoples' transition towards sustainability; however, the models, political basis and forms in which education has been delivered in indigenous contexts have not been pertinent, nor have they addressed indigenous peoples' demands and needs completely. Something similar can be foreseen regarding the implementation of the SDGs if indigenous knowledge, their history and their world views, are not taken into account, or if they are only superficially taken into account. There is enough evidence (Toledo, 2003; Shava, 2013; Smith, 1999), besides that presented in this article, of the wealth of socio-environmental knowledge in indigenous narratives that should be considered as the basis for the development of educational proposals concerning sustainability. In the framework of the SDGs, it cannot be ignored that indigenous communities have developed sustainable local practices based on their own systems of knowledge and beliefs. In this way, it is worth taking up the ethno-ecological knowledge encrusted in the daily practice of indigenous communities, because it cannot be denied that their traditional systems are still fundamental for transitioning towards future sustainable conditions. Similarly, the recognition of and respect for these systems of knowledge, together with support for their continuity, should be fundamental aspects in the design of solutions to the socio-environmental challenges facing us as a species. Therefore, there is a need to encourage the transmission of this knowledge and 
a need for its inclusion in formal education. The evidence presented in this article, based on the accounts of the fisherwomen of Zaragoza, lays the basis for demanding the implementation of the SDGs in indigenous contexts through existing local knowledge, and not just through exogenous knowledge and/or global frameworks.

The reflections presented here are the first steps towards future studies that could be carried out, in greater depth, to understand the way in which meaning is constructed in indigenous communities from situated narratives, the way in which it is passed on, the educational potential that lies in this indigenous knowledge and these narratives, and the risks involved in allowing these practices to lapse in the daily life of communities.

\section{Endnotes}

1. See https://sustainabledevelopment.un.org/sdgs

2. A kind of calabash, originally from Africa, from which jars and musical instruments are made.

3. A woven bag or sack (made of plastic or organic materials) used to carry a range of products.

\section{Notes on the contributor}

\section{Sandoval-Rivera | Juan Carlos A. | Universidad Veracruzana, Mexico \\ ORCID 0000-0001-8084-282X | jcsandoval.rivera@gmail.com}

Through audio-visual collaborative research methodologies, the author researches and supervises educational research projects on the interaction between indigenous knowledge and scientific knowledge in socio-ecological processes and the adaptation to climate change in indigenous contexts.

\section{References}

Bishop, R. (1995). Collaborative research stories: Whakawhanaungatanga. Unpublished PhD thesis, University of Otago, New Zealand.

Boff, L. (2013). La sostenibilidad. Qué es y qué no es. Santander: Sal Terrae.

George, J.M. (1999). Indigenous knowledge as a component of the school curriculum. In L.M. Semalib \& J.L. Kincheloe (Eds), What is indigenous knowledge? Voices from the academy (pp. 79-94). New York: Falmer Press.

González-Gaudiano, E. (2001). Otra lectura de la historia de la educación ambiental en América latina. Revista Desenvolvimento e Meio Ambiente, 3, 141-158.

Grenier, L. (1998). Working with indigenous knowledge: A guide for researchers. Ottawa: IDRC.

INALI (Instituto Nacional de las Lenguas Indígenas). (2008). Catálogo de las Lenguas Indígenas Nacionales: variantes lingüísticas de México con sus autodenominaciones y referencias geoestadísticas. Instituto Nacional de las Lenguas Indígenas, México.

Kincheloe, J.L. \& Steinberg, S.R. (2008). Indigenous knowledges in education: Complexities, dangers, and profound benefits. In N.K. Denzin, Y.S. Lincoln \& L.T. Smith (Eds), The handbook of critical and indigenous methodologies (pp. 135-156). Thousand Oaks: SAGE. 
Maurial, M. (1999). Indigenous knowledge and schooling: A continuum between conflict and dialogue. In L.M. Semali \& J.L. Kincheloe (Eds), What is indigenous knowledge? Voices from the academy (pp. 135-156). New York: Falmer Press.

Olivé, L. (2009). Por un auténtica interculturalidad basada en el reconocimiento de la pluralidad epistemológica. En: Luís, Tapia (coord.). Pluralismo epistemológico (pp. 19-30). La Paz, Bolivia: Muela del Diablo Editores.

Reynar, R. (1999). Indigenous people's knowledge and education: A tool for development. In L.M. Semali \& J.L. Kincheloe (Eds), What is indigenous knowledge? Voicesfromtheacademy (pp. 285-304). New York: Falmer Press.

Sandoval-Rivera, J.C. (2015). Los Herederos de Achaneh: Educación Intercultural y diálogo de saberes en la documentación audiovisual de prácticas tradicionales sustentables en el sur de Veracruz. Unpublished $\mathrm{PhD}$ thesis. Instituto de Investigaciones en Educación, Xalapa, Universidad Veracruzana, Mexico.

Santos, B. (2006). La Sociología de las Ausencias y la Sociología de las Emergencias: para una ecología de saberes. En: B. de Sousa Santos: Renovar la teoría crítica y reinventar la emancipación social (pp. 13-41). Buenos Aires: CLACSO.

Shava, S. (2013). The representation of indigenous knowledge. In R.B. Stevenson, M. Brody, J. Dillon \& A. Wals (Eds), International handbook of research on environmental education (pp. 384-393). New York: Routledge.

Shava, S. \& O’Donoghue, R. (2014). Teaching indigenous knowledge and technology. Grahamstown: Fundisa for Change Programme, ELRC, Rhodes University, South Africa.

Smith, L.T. (1999). Decolonizing methodologies: Research and indigenous peoples. London: Zed Books Ltd.

Stetsenko, A. (2008). From relational ontology to transformative activist stance on development and learning: Expanding Vygotsky's (CHAT) project. Cultural Studies of Science Education, 3(2), 471-491.

Toledo, V.M. (1996). Principios etnoecológicos para el desarrollo sustentable de comunidades campesinas e indígenas. http://www.ambiental.net/temasclave/TC04ToledoEtnoecologiaPrincipios.htm

Toledo, V.M. (2003). Ecología, espiritualidad y conocimiento. De la sociedad del riesgo a la sociedad sustentable. Puebla, Mexico: PNUMA-Universidad Iberoamericana.

UNESCO (United Nations Educational, Scientific and Cultural Organization). (2015). Objetivos de Desarrollo Sostenible. 17 objetivos para transformar nuestro mundo. United Nations Educational, Scientific and Cultural Organization. http://www.un.org/ sustainabledevelopment/es/objetivos-de-desarrollo-sostenible/ 